\title{
The Effect of Nutritional Rehabilitation on Whole Body Protein Metabolism of Children with Cystic Fibrosis
}

\author{
H. G. PARSONS, P. BEAUDRY,' AND P. B. PENCHARZ \\ Department of Paediatrics, The Montreal Children's Hospital, McGill University, Montreal, Quebec and The \\ Research Institute, The Hospital for Sick Children and the Departments of Paediatrics and Nutritional Sciences, \\ The University of Toronto, Toronto, Ontario, Canada
}

\begin{abstract}
The effect of an increased energy and protein intake was studied on the whole body protein metabolism of 4- to 9-yr-old children with cystic fibrosis. The study was divided into an initial 1-yr period, followed by a treatment period of the same length. Rates of protein turnover were determined using a $\left.{ }^{15} \mathrm{~N}\right]$ glycine label and the Picou and Taylor-Roberts model. The children had significantly higher intakes during the treatment year and grew faster. Nitrogen retention and utilization were significantly increased during the treatment year $(p<0.01)$. There were no changes seen in whole body amino nitrogen flux, or protein synthesis rates. However, protein breakdown rates were significantly reduced during the treatment period, with the result that net anabolism (synthesis-breakdown) was increased $(p<0.05)$. The protein synthesis rates of about $6 \mathrm{~g} / \mathrm{kg} /$ day were similar to those reported for healthy children of the same age. It was concluded that the changes in protein turnover seen were in response to the nutritional intervention and not to the chlildren's basic genetic disease process. (Pediatr Res 19: 189-192, 1985)
\end{abstract}

\section{Abbreviations}

CF, cystic fïbrosis

$Q$, whole body amino acid flux

$\mathbf{S}$, protein synthesis, anabolism

B, protein breakdown, catabolism

Many children with $\mathrm{CF}$ are retarded in their growth. This retardation appears to be mainly due to insufficient energy intake (1). Despite the appropriate use of exocrine pancreatic supplements, which correct most of the maldigestion (2), many children remain with a significant degree of growth retardation. This growth failure can be reversed and normal growth rates achieved with an increase in total food intake and hence, in absorbed energy intake $(1,3)$. The present study was designed to examine the effect of nutritional rehabilitation achieved by dietary coun-

Received December 7, 1983; accepted October 2, 1984

Dr. H. G. Parsons, Division of Gastroenterology and Nutrition, Department of Paediatrics, Faculty of Medicine, Health Sciences Centre, 3330 Hospital Drive NW, Calgary, Alberta, Canada T2N 4N1.

Dr. Paul B. Pencharz, Head, Division of Clinical Nutrition, The Hospital for Sick Children, 555 University Avenue, Toronto, Ontario, Canada, M5G 1 X8.

Supported by both The Canadian Cystic Fibrosis Foundation and The Medical Research Council of Canada, Grant MA-5466.

' Current address: The Children's Hospital of Eastern Ontario, 401 Smyth Road, Ottawa, Ontario, Canada K1H 8L1. seling and food supplementation on the protein metabolism of children with $\mathrm{CF}$ within a larger program looking at the effect of such rehabilitation on the growth of these children (3).

\section{MATERIALS AND METHODS}

The study group consisted of eight children aged 4 to 9 yr in whom CF had been diagnosed for at least 2 yr. All entered the study voluntarily and with parental consent. The study was approved by the Ethics Committee of the Montreal Children's Hospital. The 1st yr of the program (control period) consisted of careful observation and analysis of dietary intake of these children with no attempt at intervention. During the 2nd yr (test period) of the program, in an effort to improve their growth, the children were encouraged to eat more total food and to take a variety of energy-rich drinks. A complete description of the program has been previously published (3). The energy-rich drinks were based on recipes devised by our dietitian and were made at home with milk, vegetable oil (corn or soy), corn syrup and sugar, plus food flavoring agents. The energy density of the drinks was $1 \mathrm{kcal} / \mathrm{ml}$ and the proportions of energy in the supplement were 12,63 , and $24 \%$ for protein, carbohydrate, and fat, respectively. The subjects were seen in the clinic every 2 months and were questioned regarding their food and supplement intake and encouraged to continued and to increase their energy intake, aiming at at least $130 \%$ of requirement level (3).

Weight and height were measured at the start of the study and then at each clinic visit. The children were clinically stable during the study. Details of their clinical status and bone age have been published previously (3). Height and weight growth velocities were expressed as SD scores for sex and age (3). SD scores were calculated using the formula, $\mathrm{SD}$ scores $=(\mathrm{x}-\overline{\mathrm{x}}) / \mathrm{Sx}$, where $\mathrm{x}$ is the patient's measurements, $\bar{x}$ is the 50 th percentile value of normal children of the same age and sex (4), and Sx is the SD for the particular year and sex (4).

During the 4th month of the control period and the 6th month of the test period, the children were admitted to the hospital for a 3-day metabolic balance and protein turnover study. ${ }^{2}$ The subjects were fed a balanced North American diet ad libitum. Dietary protein and energy intakes were estimated using standard food composition tables (5). Urine and feces were analyzed for total nitrogen by micro-Kjeldhal technique (6). Fecal energy content was determined by oxygen bomb calorimetry.

To study the dynamic aspects of whole body nitrogen metabolism, a modification of the Picou and Taylor-Roberts (7) ap-

${ }^{2}$ Our experimental design called for the metabolic studies to be carried out in the middle of the particular study period. The choice of the 4th and 6 th months was for convenience to fit in with school holidays, thus avoiding having to take the children out of school. 
proach was used $(8,9)$. $\left[{ }^{15} \mathrm{~N}\right]$ glycine 95 atoms \% enriched (Merck Sharp Dohme Ltd, Dorval, Quebec, Canada) was dissolved in distilled water and administered orally every $3 \mathrm{~h}$ for a total of 72 $\mathrm{h}$, in a dose of $0.6 \mathrm{mg}{ }^{15} \mathrm{~N} / \mathrm{kg} /$ day. Urine was collected immediately before each dose of $\left[{ }^{15} \mathrm{~N}\right]$ glycine and at the end of the study for $\left[{ }^{15} \mathrm{~N}\right]$ urea analysis. The enrichment of the $\left[{ }^{15} \mathrm{~N}\right]$ glycine was verified by mass spectroscopy. Urinary urea nitrogen was isolated as previously described $(9,10)$ and its ${ }^{15} \mathrm{~N}$ content determined by dual inlet collector isotope ratio mass spectrometer (Vacuum Generators, Micromass 602D, Winsford, Cheshire, UK) (11).

\section{DATA ANALYSIS}

The ${ }^{15} \mathrm{~N}$ enrichment of urinary urea was calculated as previously described $(9,10)$. The achievement of an isotopic steady state in urinary ${ }^{15} \mathrm{~N}$-urea was determined by both visual inspection $(7,9,12)$ and computer prediction (13). Once the steady state isotopic plateau was reached (usually by $24 \mathrm{~h}$ after the study started), the urinary $\left[{ }^{15} \mathrm{~N}\right]$ urea enrichment was averaged for the next 24-h period in order to allow for any diurnal variation caused by meal feeding (13). This mean value of the isotopic plateau was then used to estimate rates of whole body amino acid flux (Q), protein synthesis (S), and protein breakdown (B) using the Picou and Taylor-Roberts model (7).

Statistical comparisons were performed using paired $t$ tests and correlation analysis.

\section{RESULTS}

Clinical parameters of the children upon entering the study are shown in Table 1 . There were no changes in the disease activity score over the $2 \mathrm{yr}$ of the study. Mean height and weight growth velocities of the children converted to SD scores are listed in Table 2. A SD score of zero indicates a normal average rate of growth compared with the reference population (4). Thus, during the control year the children were showing inadequate growth in both height and weight. With the increased energy ingested during the 2nd yr (Table 3 ), the children showed normal growth rates. Weight growth velocity was significantly increased $(p<0.05)$ during the test period and was correlated in absorbed energy intake (3). Height velocity was also increased $(p<0.10$ but $>0.05$ ). Intake of nitrogen and energy and nitrogen balance were significantly increased during the test period compared with the control period (Table 3 ). Net nitrogen retention ( $\mathrm{N}$ balance/ $\mathrm{N}$ intake $\times 100)$ was also improved during the test period $(30.9 \%$ \pm 1.7 versus $20.2 \% \pm 1.7)(p<0.01)$.

We examined intake data, nitrogen balance, and protein turnover data of the two nonsteatorrheic subjects (nos. 7 and 8) compared with the other six subjects for differences using a Mann Whitney U test (14). No significant differences were found.
We also performed the paired comparisons (i.e. control $c f$ treatment periods) with and without the nonsteatorrheic children and it did not change our conclusions. Therefore, we felt justified to include all the subjects in our analyses.

Rates of total body amino nitrogen flux, protein synthesis, and breakdown are shown in Table 4. No changes were seen between the two study periods for either $Q$ or $S$. The rates of protein breakdown were, however, significantly reduced $(p<0.05)$. Net protein synthesis (S-B) was also significantly increased during the test period $(p<0.01)$. This parameter represents the net balance between anabolism (S) and catabolism (B). The economy of whole body nitrogen metabolism is shown in Table 5. During the test period there was a reduction in the fraction of the amino nitrogen flux utilized for protein synthesis (S/Q) $(p<0.05)$ and in the proportion of flux coming from endogenous protein breakdown (B/Q) $(p<0.05)$.

Protein and energy intakes and growth rate were examined for correlations to the parameters of protein turnover. No relationship was seen with energy intake. However, protein intake correlated inversely with the fraction of amino nitrogen flux coming from endogenous protein breakdown $(B / Q)$ during both study periods $(p<0.01)$. Linear growth velocity during the treatment year correlated inversely with amino nitrogen flux $(p<0.05)$, protein synthesis $(p<0.05)$, and breakdown $(p<0.05)$. Weight growth velocity, however, did not correlate with any of the protein turnover parameters.

\section{DISCUSSION}

The level of protein and energy that these children took during the balance periods was comparable to their intake at home. Thus, the higher voluntary intake during the test balance study reflected the higher intake during the test period. The improved efficiency of nitrogen retention can be attributed to the higher absorbed energy intake. During the control period, height and weight growth were less than the normal population, whereas during the test year, growth was occurring at the same rate as the standard population for sex and age (4).

We have recently demonstrated a diurnal variation in urinary

Table 2. Growth velocities for ht and wt (mean \pm SEM)

\begin{tabular}{lcc}
\hline & $\begin{array}{l}\text { Ht growth } \\
\text { (SD score) }\end{array}$ & $\begin{array}{c}\text { Wt growth } \\
\text { (SD score) }\end{array}$ \\
\hline Control yr & $-1.03 \pm 0.54$ & $-1.14 \pm 0.23$ \\
Test yr & $+0.26 \pm 0.70$ & $+0.30 \pm 0.33$ \\
Change (test-control yr) & $+1.29 \pm 0.71^{*}$ & $+1.44 \pm 0.52 \dagger$ \\
\hline
\end{tabular}

* Paired $t$ test $[p<0.10>0.05$ (one-tailed)].

$\dagger$ Paired $t$ test $[p<0.05$ (one-tailed)].

Table 1. Characteristics of eight CF children upon entry to study

\begin{tabular}{|c|c|c|c|c|c|c|c|}
\hline Subject* & Sex & $\begin{array}{c}\text { Age } \dagger \\
(\mathrm{yr})\end{array}$ & $\begin{array}{c}\mathrm{Ht} \\
(\mathrm{cm})\end{array}$ & $\begin{array}{l}\mathrm{Wt} \\
(\mathrm{kg})\end{array}$ & $\begin{array}{c}\mathrm{Ht}-\% \text { of } \\
\text { ideal } \neq\end{array}$ & $\begin{array}{c}\text { Wt_\% ideal } \\
\text { for ht } \ddagger\end{array}$ & $\begin{array}{c}\text { Disease activity } \\
\text { index } \S\end{array}$ \\
\hline 1 & $\mathbf{F}$ & 4.2 & 91.3 & 11.9 & 89.7 & 85.0 & 62 \\
\hline 2 & $\mathrm{~F}$ & 4.1 & 93.5 & 13.2 & 92.6 & 91.0 & 77 \\
\hline 3 & $F$ & 4.2 & 102.0 & 15.1 & 100.2 & 90.4 & 62 \\
\hline 4 & $\mathrm{~F}$ & 7.7 & 126.0 & 25.1 & 102.4 & 98.1 & 70 \\
\hline 5 & $\mathbf{M}$ & 5.4 & 111.6 & 20.0 & 100.9 & 102.6 & 87 \\
\hline 6 & $\mathbf{M}$ & 6.9 & 127.0 & 25.3 & 105.9 & 100.4 & 75 \\
\hline 7 & M & 5.0 & 100.0 & 14.5 & 92.3 & 89.5 & 75 \\
\hline 8 & $\mathbf{M}$ & 6.6 & 113.3 & 17.9 & 95.9 & 89.1 & 52 \\
\hline Mean \pm SEM & & $5.51 \pm 0.49$ & $108.1 \pm 4.85$ & $17.88 \pm 1.83$ & $97.5 \pm 2.02$ & $98.3 \pm 2.20$ & \\
\hline
\end{tabular}

* Subjects 7 and 8 were nonsteatorrheic.

$\dagger$ Age is given in yr to the first decimal.

$\ddagger$ Tanner et al. (4).

$\S$ Modified Swachman score (19). 
Table 3. Net nitrogen and energy intake and $N$ balance

\begin{tabular}{|c|c|c|c|c|c|c|}
\hline \multirow[b]{3}{*}{ Subject } & \multicolumn{3}{|c|}{ Control period } & \multicolumn{3}{|c|}{ Test period } \\
\hline & \multicolumn{2}{|c|}{ Intake } & \multirow{2}{*}{$\begin{array}{c}\text { Nitrogen } \\
\text { balance } \\
\text { (mg/kg/day) }\end{array}$} & \multicolumn{2}{|c|}{ Intake } & \multirow{2}{*}{$\begin{array}{c}\text { Nitrogen } \\
\text { balance } \\
\text { (mg/kg/day) }\end{array}$} \\
\hline & $\begin{array}{c}\text { Nitrogen } \\
\text { (mg/kg/day) }\end{array}$ & $\begin{array}{c}\text { Energy } \\
\text { (kcal/kg/day) }\end{array}$ & & $\begin{array}{c}\text { Nitrogen } \\
\text { (mg/kg/day) }\end{array}$ & $\begin{array}{c}\text { Energy } \\
\text { (kcal/kg/day) }\end{array}$ & \\
\hline 1 & 369 & 58 & 100 & 559 & 91 & 190 \\
\hline 2 & 411 & 74 & 40 & 558 & 79 & 110 \\
\hline 3 & 669 & 96 & 260 & 733 & 78 & 320 \\
\hline 4 & 559 & 67 & 100 & 665 & 81 & 230 \\
\hline 5 & 313 & 45 & -10 & 398 & 77 & 60 \\
\hline 6 & 443 & 60 & 50 & 440 & 66 & 50 \\
\hline 7 & 603 & 74 & 190 & 698 & 99 & 310 \\
\hline 8 & 356 & 47 & 100 & 816 & 88 & 360 \\
\hline
\end{tabular}

Mean \pm SEM

$464 \pm 16$

$65 \pm 2$

$104 \pm 11$

$608 \pm 18$

$82 \pm 1$

$204 \pm 15$

* Nitrogen and energy intake $(p<0.05)$ and nitrogen balance $(p<0.01)$ both increased significantly during the test period when analyzed using paired $t$ tests.

Table 4. Total amino nitrogen flux rate $(Q)$, protein synthesis $(S)$, and breakdown $(B)$

\begin{tabular}{|c|c|c|c|c|c|c|}
\hline \multirow[b]{2}{*}{ Subject } & \multicolumn{2}{|c|}{$\mathrm{Q}$} & \multicolumn{2}{|c|}{$S$} & \multicolumn{2}{|c|}{ B } \\
\hline & $\begin{array}{c}\text { Control } \\
\text { period } \\
(\mathrm{g} \mathrm{N} \\
\end{array}$ & $\begin{array}{c}\text { Test } \\
\text { Period } \\
\text { day) }\end{array}$ & $\begin{array}{c}\text { Control } \\
\text { period } \\
(\mathrm{g} \text { prot }\end{array}$ & $\begin{array}{c}\text { Test } \\
\text { period } \\
\mathrm{kg} / \text { day })\end{array}$ & $\begin{array}{c}\text { Control } \\
\text { period } \\
\text { (g pro }\end{array}$ & $\begin{array}{c}\text { Test } \\
\text { period } \\
\text { g/day) }\end{array}$ \\
\hline 1 & 1.19 & 1.18 & 5.82 & 5.03 & 5.20 & 3.86 \\
\hline 2 & 1.68 & 1.67 & 8.01 & 5.69 & 7.95 & 6.95 \\
\hline 3 & 1.62 & 1.37 & 7.66 & 6.17 & 5.96 & 4.00 \\
\hline 4 & 1.27 & 1.23 & 5.10 & 5.01 & 4.46 & 3.56 \\
\hline 5 & 1.28 & 1.08 & 5.96 & 4.63 & 5.58 & 4.25 \\
\hline 6 & 1.25 & 1.49 & 5.87 & 6.88 & 5.04 & 6.55 \\
\hline 7 & 1.22 & 1.22 & 5.44 & 5.29 & 3.87 & 3.28 \\
\hline 8 & 1.27 & 1.42 & 6.35 & 6.12 & 5.72 & 3.76 \\
\hline Mean $\pm \mathrm{SEM}$ & $1.28 \pm 0.02$ & $1.35 \pm 0.02$ & $6.28 \pm 0.13$ & $5.60 \pm 0.10$ & $5.47^{*} \pm 0.15$ & $4.53^{*} \pm 0.18$ \\
\hline
\end{tabular}

*Values for protein breakdown were reduced significantly during the test period $(p<0.05)$ when analyzed by paired $t$ test.

Table 5. Economy of whole body nitrogen metabolism

\begin{tabular}{cccccc}
\hline & \multicolumn{2}{c}{ S/Q (\%) } & & \multicolumn{2}{c}{ B/Q (\%) } \\
\cline { 2 - 3 } \cline { 5 - 6 } Subject & $\begin{array}{c}\text { Control } \\
\text { period }\end{array}$ & $\begin{array}{c}\text { Test } \\
\text { period }\end{array}$ & & $\begin{array}{c}\text { Control } \\
\text { period }\end{array}$ & $\begin{array}{c}\text { Test } \\
\text { period }\end{array}$ \\
\hline 1 & 78.2 & 68.3 & & 69.9 & 52.5 \\
2 & 76.2 & 54.5 & & 75.6 & 66.6 \\
3 & 75.5 & 71.9 & & 58.8 & 46.6 \\
4 & 64.0 & 64.9 & & 56.1 & 46.2 \\
5 & 74.6 & 68.7 & & 69.8 & 63.1 \\
6 & 75.1 & 74.0 & & 64.5 & 70.4 \\
7 & 71.2 & 69.2 & & 50.7 & 42.9 \\
8 & 80.0 & 69.1 & & 72.0 & 42.5
\end{tabular}

\footnotetext{
Mean \pm SEM $\quad 74.4^{*} \pm 0.6 \quad 67.6^{*} \pm 0.7 \quad 64.7^{*} \pm 1.1 \quad 53.8^{*} \pm 1.4$
}

* Values for the test period were significantly less than those for the control period $(p<0.05)$ when analyzed by paired $t$ test.

$\left[{ }^{15} \mathrm{~N}\right]$ urea excretion and in the parameters of protein turnover and shown that they are related to meal feeding (13). The subjects in the present study were also meal fed (as distinct from continuous 24-h feeding) and we were concerned only with the average daily turnover rates. We therefore chose to average the urinary $\left[{ }^{15} \mathrm{~N}\right]$ urea enrichments over a $24-\mathrm{h}$ period after it was judged that an isotopic steady state was achieved. A more complete discussion of the diurnal variation in urinary $\left[{ }^{15} \mathrm{~N}\right]$ urea enrichment and isotope recycling can be found in our earlier paper (13).
However, averaging the urinary $\left[{ }^{15} \mathrm{~N}\right]$ urea isotopic enrichments from 24 to $48 \mathrm{~h}$ of each study provided a reasonable estimate of daily protein turnover average rates and minimized any effects due to isotope recycling (13).

The rates for whole body amino nitrogen flux, protein synthesis, and breakdown in the present study are similar to those that we have reported in obese adolescents (15). They are also similar to the rates reported by Picou and Taylor-Roberts (7) in children 10 to 20 months of age of normal nutritional status, Kein et al. (16) for children 4 to 10 yr old recently recovered from burns, and by Adenyi-Jones et al. (17) in prepubertal children. There is therefore no evidence that the basic disease (CF) has any effect on the protein metabolism of these children.

Our results are in keeping with the data of Adenyi-Jones $e$ t al. (17) who have shown that the increased rate of growth during puberty can be accounted for by reduction in whole body protein breakdown rather than by an changes in amino nitrogen flux or protein synthesis. Other studies have shown that rates of protein turnover (i.e. both synthesis and breakdown) are increased during the first few weeks of nutritional rehabilitation $(8,19)$. It is possible that if studies had been done in the first few weeks of the increased energy intakes increased rates of turnover would have been observed. However, the test metabolic study was done at 6 months of the treatment year. It is probable, therefore, that any acute initial changes in protein metabolism would be over and the results seen represent a steady state condition.

It is of interest to note that the improved growth rates are associated with a reduction in breakdown rate and no increase in protein synthesis. The increase in lean tissue, which presum- 
ably occurred with height and weight growth, requires an increase in the body's protein content. The body's protein content in turn will increase if the net protein synthesis (S-B) is positive. Since protein synthesis is an energy expensive process $(8)$, while protein breakdown is not, the enhancement of net protein synthesis by a reduction of protein breakdown relative to protein synthesis is clearly an energy efficient adaptation permitting increased growth at a minimal energy expenditure.

Acknowledgments. The authors thank Miss Anne Dumas, Therapeutic Dietitian, The Montreal Children's Hospital, for her help with the dietary aspects of this study and Dr. Margaret Wood for her help with the statistical aspects of the study.

\section{REFERENCES}

1. Pencharz PB 1983 Energy intakes and low fat diets in children with cystic fibrosis. J Pediatr Gastoenterol Nutr 2:400-402

2. Lapey A, Kattwinkel J, di Sant'Agnese PA, Laster E 1974 Steatorrhea and azotorrhea and their relation to growth and nutrition in adolescents and young adults with cystic fibrosis. J Pediatr 84:328-334

3. Parsons HG, Beaudry P, Dumas A, Pencharz PB 1983 Energy needs and growth in children with cystic fibrosis. J Pediatr Gastroenterol Nutr 2:44-49

4. Tanner JM, Whitehouse RH, Takaishi M 1966 Standards from birth to maturity for height, weight, height velocity and weight velocity: British children, 1965. Part II. Arch Dis Childh 41:613-635

5. Bell L, Hatcher J, Chan L, Fraser D 1979 Development of a computerized system for calculating nutrient intakes. J Can Diet Assoc 40:30-36

6. Munro HN, Fleck A 1969 Analysis of tissues and body fluids for nitrogenous constituents. In: Munro HN (ed) Mammalian Protein Metabolism, Vol IIII. Academic Press, New York, pp 423-525
7. Picou D Taylor-Roberts T 1969 The measurement of total body protein synthesis and catabolism and nitrogen turnover in infants in different nutritional status and receiving different amounts of dietary protein. Clin Sci 36:283-296

8. Pencharz PB, Parsons HG, Motil KJ, Duffy BJ 1981 Total body protein turnover and growth in children: is it a futile cycle? Med Hypoth 7:155-160

9. Steffee WP, Goldsmith RS, Pencharz PB, Scrimshaw NS, Young VR 1976 Dietary protein intake in the dynamic aspects of whole body protein metabolism in adult humans. Metabolism 25:281-297

10. Pencharz PB, Steffee WP, Cochran W, Scrimshaw NS, Rand WM, Young VR 1977 Protein metabolism in human neonates. Clin Soc Mol Med 52:485498

11. Pencharz PB, Masson M, Desgranges F, Papageorgious A 1981 Total body protein turnover in human premature neonates: effects of birthweight, intrauterine nutritional status and diet. Clin Sci 61:207-215

12. Duffy B, Gunn T, Collinge J, Pencharz PB 1981 The effect of varying protein quality and energy intake on the nitrogen metabolism of parenterally fed very low birthweight $(<1600 \mathrm{~g})$ infants. Pediatr Res 15:1040-1044

13. Parsons HG, Wood MM, Pencharz PB 1983 Diurnal variation in urine ${ }^{15} \mathrm{~N}$ urea content, estimates of whole body protein turnover, and isotope recycling in healthy meal-fed children with cystic fibrosis. Can J Physiol Pharmacol 61:72-80

14. Siegal S 1956 Non-parametric Statistics for Behavioural Sciences. McGrawHill, Toronto

15. Pencharz PB, Motil KJ, Parsons HG, Duffy BJ 1980 The effect of an energy restricted diet on the protein metabolism of obese adolescents: nitrogen balance and whole body protein turnover. Clin Sci 59:13-18

16. Kien CL, Young VR, Rohrbaugh DK, Burke JM 1978 Whole body protein synthesis and breakdown rates in children before and after reconstructive surgery of the skin. Metabolism 27:27-34

17. Adenyi-Jones SJ, Suskind R, Polombo J, Pena Cruz V, Kaw KT 1979 Growth at puberty: possible mechanism of increased growth from protein turnover and energy balance studies. Pediatr Res 13:326 (abstr)

18. Waterlow JC, Golden MHN, Garlick PJ 1978 Protein turnover in man measured with ${ }^{15} \mathrm{~N}$ : comparison of end-product and dose regimes. Am J Physiol 235:E165-E174

\title{
A Differential Effect of Thyroxine and Glucocorticoids on Fetal Brain and Heart Insulin Receptor
}

\author{
SHERIN U. DEVASKAR, PAUL F. GRIM III, AND UDAY P. DEVASKAR \\ Division of Perinatal-Neonatal Medicine, Department of Pediatrics, Saint Louis University School of Medicine, \\ Pediatric Research Institute, Cardinal Glennon Memorial Hospital for Children, St. Louis, Missouri 63104
}

\begin{abstract}
We investigated the effect of thyroxine (T4), glucocorticoids, and T4 + glucocorticoids on the maturation of fetal rabbit brain and heart insulin receptors. Five doses of $\mathrm{T} 4 \mathrm{over} 10$ days $(50 \mu \mathrm{g} / \mathrm{kg}$ body weight per dose) were administered to the mother; significant amounts crossed the placenta (fetal serum free $\mathrm{T} 4=0.75 \pm 0.08$ versus a control of $0.21 \pm 0.02 \mathrm{ng} / \mathrm{dl}, p<0.02$ ) and increased the specific binding of $\left[{ }^{125} I\right]$ insulin to 30 -day-old fetal heart membranes from a control of $3.6 \pm 0.74 \%$ per $100 \mu \mathrm{g}$ protein to $5.8 \pm 0.19 \%(p<0.05)$. Curvilinear
\end{abstract}

Received December 30, 1983; accepted October 3, 1984.

Reprint requests Sherin U. Devaskar, M.D., Room No. 519, Glennon Hall, 1465, S. Grand Boulevard, St. Louis, MO 63104.

Supported in part by the American Heart Association-Missouri Affiliate, The National American Diabetes Association and the Biomedical Research Support Grant (NIH RR05388)
Scatchard plots revealed an increase in receptor number $x$ $10^{7} \mu$ protein $^{-1}$ from $137 \pm 4$ to $244 \pm 39(p<0.05)$ with no change in receptor affinity. No appreciable alteration by $T 4$ in the $\left[{ }^{125}\right.$ I]insulin-specific binding and receptor number of 30-day fetal brains was noted. Fetal heart glycogen content was decreased and there was a small increase in plasma glucose concentration in the T4-treated group (each $p<0.02$ ). Betamethasone at $0.17 \mathrm{mg} / \mathrm{kg}$ did not affect the specific binding of $\left[{ }^{125} \mathrm{I}\right]$ insulin to 27 -day fetal heart or brain plasma membranes, although a decrease in heart glycogen content and an increase in plasma glucose concentration were observed (each $p<0.02$ ). Also T4 + betamethasone did not alter the $\left[{ }^{125}\right.$ I]insulin binding to 27 day fetal heart or brain plasma membranes, but resulted in an additive effect (a marked depletion) on cardiac glycogen $(p<0.001)$. Brain glycogen was undetectable in all 